\title{
Photoelectrochemical evaluation of pH effect on hole transport through triplex-forming DNA immobilized on a gold electrode
}

\section{AUTHOR(S):}

Haruna, Ken-ichi; lida, Haruka; Tanabe, Kazuhito; Nishimoto, Sei-ichi

\section{CITATION:}

Haruna, Ken-ichi ... [et al]. Photoelectrochemical evaluation of pH effect on hole transport through triplex-forming DNA immobilized on a gold electrode. Organic \& Biomolecular Chemistry 2008, 6(9): 1613-1617

\section{ISSUE DATE:}

2008-05

URL:

http://hdl.handle.net/2433/85294

\section{RIGHT:}

Org. Biomol. Chem., 2008, 6(9), pp.1613-1617 - Reproduced by permission of The Royal Society of Chemistry (RSC); This is not the published version. Please cite only the published version.; この論文は出版社版でありません。引用の際には出版社版をご確認 ご利用ください。 


\title{
Photoelectrochemical Evaluation of pH Effect on Hole Transport through Triplex-Forming DNA Immobilized on a Gold Electrode
}

\author{
Ken-ichi Haruna, ${ }^{*}$ Haruka Iida, Kazuhito Tanabe* and Sei-ichi Nishimoto* \\ Department of Energy and Hydrocarbon Chemistry, Graduate School of Engineering, \\ Kyoto University, Katsura Campus, Kyoto 615-8510, Japan
}

*corresponding author. Phone: +81-75-383-2500. FAX: +81-75-383-2501,

e-mail: hrn@pg.highway.ne.jp, tanabeka@scl.kyoto-u.ac.jp,nishimot@scl.kyoto-u.ac.jp 


\section{Graphical Abstract}
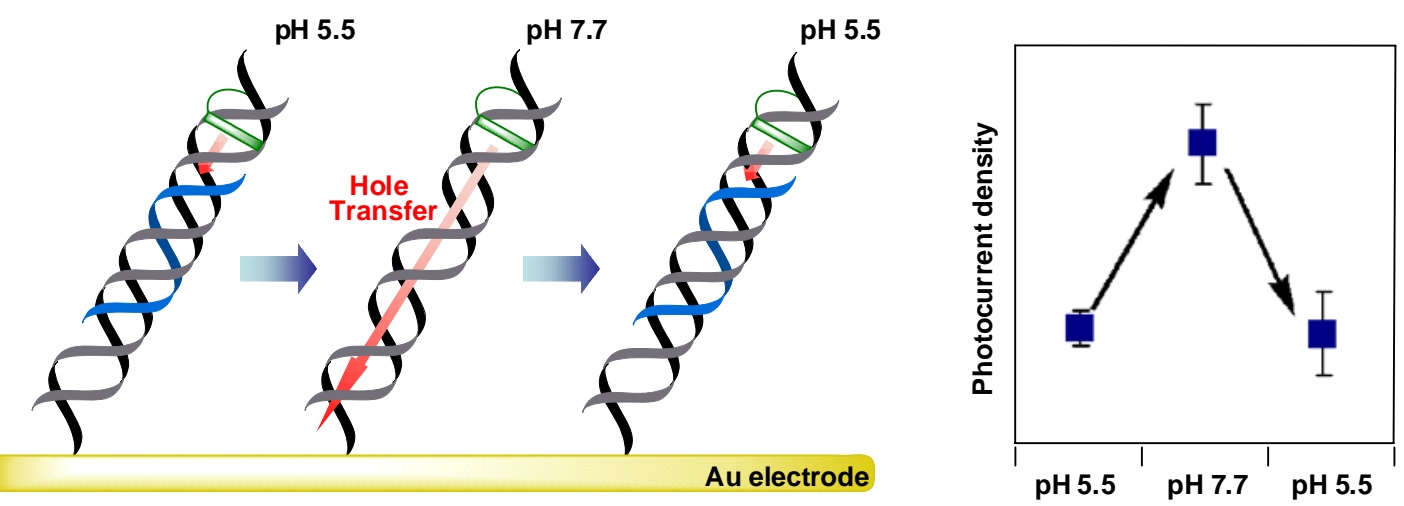

We characterized the $\mathrm{pH}$ effect on the hole transport through a photosensitizer-tethered DNA duplex

possessing a partial triplex-forming region by measurement of photocurrent response of a DNA system immobilized on a gold electrode. 


\section{Abstract}

We characterized a $\mathrm{pH}$ effect on the hole transport through DNA duplexes possessing a partial triplex-forming region. Direct electrochemical measurement of the current response of photosensitizer-tethered DNA immobilized on a gold electrode revealed that the partial triplex formation under acidic conditions suppressed photocurrent due to hole transport, while dissociation of the triplex into the duplex as occurred upon increasing $\mathrm{pH}$ values recovered the photocurrent efficiency. Reversible conversion between duplex and triplex induced upon cyclic alternation of $\mathrm{pH}$ values resulted in a rise and fall of photocurrent responses, indicating that $\mathrm{pH}$ change may feature in the switching function of hole transport in DNA. These electrochemical behaviors could be correlated to the results obtained in the long-range photo-oxidative DNA cleavage experiments, in which DNA cleavage at the hole trapping site beyond the triplex region was significantly suppressed under triplex-forming acidic conditions. 


\section{Introduction}

Hole transport in DNA is a remarkable characteristic of double helical DNA. ${ }^{1}$

Since the phenomenon was firstly reported, a large number of studies have illustrated that the efficiency of DNA-mediated hole transport reaction is strongly dependent on the DNA base sequence, conformational dynamics and local flexibility. ${ }^{1 \mathrm{a}, \mathrm{d}}$ These reaction characteristics may provide a fundamental basis for possible applications of the hole transport to a gene analysis of mutation and a molecular wire in the electronic nano-devices. $^{2,3}$

A $\mathrm{pH}$ change is among the potential external triggers for regulation of various functions of biosystems such as biosensors, supramolecules and drugs. ${ }^{4}$ DNA triplex may be a pH-responsive nano-material, in which an oligopyrimidine as the third strand associates with the corresponding DNA duplex via Hoogsteen hydrogen bonding under acidic conditions, but dissociates to form the original duplex under basic conditions. ${ }^{5}$ Recently, we have displayed the effect of a partial triplex formation on the hole transport in the DNA duplexes by electrochemical measurements. ${ }^{6}$ Anthraquinone (AQ)-photosensitized hole transport through DNA was substantially arrested by triplex formation in contrast to the efficient hole transport in the DNA duplexes. ${ }^{7}$ In this context, change in $\mathrm{pH}$ value may be a sensitive tool for regulation of hole transport in 
the DNA duplex by $\mathrm{pH}$-dependent triplex formation and dissociation.

In this study, we measured the photocurrent response of a DNA system, in which the DNA duplex-triplex equilibrium in the presence of an oligopyrimidine short strand was regulated with varying $\mathrm{pH}$ values, in order to characterize the $\mathrm{pH}$ effect on the hole transport through a DNA duplex. The photocurrent response of an anthraquinone (AQ) photosensitizer-tethered DNA duplex possessing a partial triplex region revealed that the hole transport was effectively suppressed by the triplex formation under acidic conditions $(\mathrm{pH}$ 5.5), while being recovered under basic conditions ( $\mathrm{pH}$ 7.7) favoring dissociation of the triplex to a duplex. Furthermore, cyclic alternation of $\mathrm{pH}$ values between 5.5 and 7.7, which induced reversible triplex-duplex conversions, resulted in a fall-rise photocurrent responses. These results indicate that the pH change can regulate the photoinduced hole transport. In a long-range photo-oxidative DNA cleavage experiment, we also confirmed $\mathrm{pH}$-dependent suppression of the hole transport by a partial triplex formation.

(Fig. 1) 


\section{Results and Discussion}

Oligodeoxynucleotides (ODNs) listed in Figure 1 were prepared for evaluation of several properties. The melting behavior of Triplex I (ODN 1/ ODN 2/ ODN 3) was measured by UV spectroscopy in a buffer solution $(10 \mathrm{mM}$ sodium cacodylate, $2 \mathrm{mM}$ $\mathrm{MgCl}_{2}$ ) at a given $\mathrm{pH}$ value to confirm the triplex formation. The melting curve of Triplex I at $\mathrm{pH} 5.5$ showed two transitions at temperatures of $T_{\mathrm{m}}=29.5$ and $67.1{ }^{\circ} \mathrm{C}$, as is a typical behavior of the system involving triplex formation of the duplex with a short strand of oligonucleotide (see Figure $\mathrm{S} 1 \mathrm{a}$ ). Thus, the transition at lower $T_{\mathrm{m}}$ is assigned to the dissociation of ODN 3 from Triplex $\mathbf{I}$, and the higher $T_{\mathrm{m}}$ corresponds to melting of the resulting duplex into single strands. On the other hand, the lower transition was disappeared in the melting curve of Triplex $\mathbf{I}$ at $\mathrm{pH} 7.7$, indicating that ODN 3 spontaneously dissociated from the triplex under weakly basic conditions. These melting characteristics of Triplex I suggest that the triplex formation could be regulated by alternating $\mathrm{pH}$ values between 5.5 and 7.7 .

We also measured photocurrent responses due to AQ-photosensitized hole transport in Triplex I immobilized on a gold electrode. ${ }^{8}$ The DNA-immobilized gold electrodes $\left(2 \mathrm{~mm}^{2}\right.$ in area) were prepared by immersing in a thiolated ODN 1 solution, followed by exposure to $1 \mathrm{mM}$ mercaptohexanol to minimize nonspecific adsorption of 
DNA. ${ }^{9}$ The AQ-incorporated ODN 2 and the third strand ODN 3 were then hybridized with the ODN 1 immobilized on the electrode to give electrodes modified with Triplex I $\left((1.49 \pm 0.18) \times 10^{13} \mathrm{DNA} \mathrm{cm}^{-2}\right) \cdot{ }^{10}$ The photocurrent measurements were carried out using $365 \pm 5 \mathrm{~nm}$ light at a power density of $13.0 \pm 0.3 \mathrm{~mW} \mathrm{~cm}^{-2}$ with an applied potential of $500 \mathrm{mV}$ versus SCE. A stable cathodic current appeared immediately upon photoirradiation. As shown in Figure 2a, photocurrent density (current per electrode area) of Triplex I at $\mathrm{pH} 5.5$, where a typical triplex was formed, was $180.0 \pm 8.9 \mathrm{nA}$ $\mathrm{cm}^{-2}$. Upon increasing $\mathrm{pH}$ value from 5.5 to 7.7 , the photocurrent density was enhanced to a substantial extent up to a 1.6-fold increase $\left(280.8 \pm 21.9 \mathrm{nA} \mathrm{cm}^{-2}\right)$. When Triplex I was re-exposed to solution at $\mathrm{pH} 5.5$ from $\mathrm{pH}$ 7.7, the photocurrent density decreased to the original level. This reversible alternation of photocurrent density was synchronized with the cyclic $\mathrm{pH}$ change in solution between 5.5 and 7.7. In view of the melting characteristics of Triplex I, these results indicate that the hole transport through DNA duplex was effectively altered in the presence of a partial triplex region formed under acidic conditions, but was recovered as a result of dissociation of the short strand ODN 3 from the triplex into the original duplex under basic conditions. ${ }^{11}$ To confirm the effect of partial triplex formation on the hole transport, the control experiments with a duplex (Duplex I, ODN 1/ ODN 2)-modified gold electrode were further performed to 
measure the photocurrents at a given $\mathrm{pH}$. As shown in Figure $2 \mathrm{~b}$, while all photocurrent densities of Duplex I were similar to those of Triplex I observed at $\mathrm{pH} 7.7$, the changes in photocurrent response upon cyclic $\mathrm{pH}$ alternation were small. ${ }^{12}$ These results strongly suggest that partial triplex formation, as can be regulated by $\mathrm{pH}$ value, is responsible for the $\mathrm{pH}$-dependent change in photocurrent density. It is also clear from Figure $2 \mathrm{~b}$ that the efficiency of hole transport in the present duplex immobilized on the gold electrode is not affected at $\mathrm{pH} 5.5$, while cytosine is known to have a $\mathrm{pKa}$ around 5.5. Even if some bases like cytosine might be protonated at $\mathrm{pH} 5.5$, there seems to be less $\mathrm{pH}$ effect on the hole transport process in this particular case. In this relation, we confirmed that the ion strength of solution to be measured does not affect the photocurrent response (Figure 2c). ${ }^{13}$

(Fig. 2)

To obtain further insight into the effect of $\mathrm{pH}$-dependent triplex formation on the hole transport in DNA, we determined a correlation between photosensitized hole transport and subsequent piperidine-induced cleavage of Triplex II (ODN 4/ODN 5/ODN 6) consisting of AQ-tethered 24 mer ODN 5, ${ }^{32} \mathrm{P}$-labeled complementary ODN 4, 
and the third strand ODN 6 (Figure 1). ${ }^{14}$ ODN 4 in Triplex II contained two 5'-GG-3' sites of $G_{18} G_{19}$ and $G_{7} G_{8}$ across the triplex-forming region along with $G_{11} A G_{13}$ in the interior of triplex-forming region, as internal indicators for the photoinduced hole transport. ${ }^{15}$ Figure $3 \mathrm{a}$ is a representative gel picture indicating the result of photoirradiation at $\mathrm{pH} 5.5,6.2,6.8$ and 7.7, and Figure $3 \mathrm{~b}$ graphically shows quantitative comparisons of the normalized amounts of oxidative cleavage at $\mathrm{G}_{18} \mathrm{G}_{19}$, $\mathrm{G}_{11} \mathrm{AG}_{13}$ and $\mathrm{G}_{7} \mathrm{G}_{8}$ as a function of $\mathrm{pH}$ value. ${ }^{16}$ Under neutral and basic conditions at $\mathrm{pH}$ $>$ 6.8, where ODN 6 favors dissociation from Triplex II to form the corresponding duplex (Duplex II, ODN 4/ ODN 5), ${ }^{17}$ the DNA cleavage occurred in larger amounts at $\mathrm{G}_{18} \mathrm{G}_{19}$ and $\mathrm{G}_{7} \mathrm{G}_{8}$, while in smaller amount at $\mathrm{G}_{11} \mathrm{AG}_{13}$. This DNA cleavage profile implicates that the photoinjected hole could be distributed over the base sequences inserted between the indicator sites of $\mathrm{G}_{18} \mathrm{G}_{19}$ and $\mathrm{G}_{7} \mathrm{G}_{8}$. In contrast, under acidic conditions at $\mathrm{pH}<6.8$, the DNA cleavage at $\mathrm{G}_{18} \mathrm{G}_{19}$ as located adjacent to the AQ-photosensitizer occurred to a greater extent relative to those at $\mathrm{G}_{11} \mathrm{AG}_{13}$ and $\mathrm{G}_{7} \mathrm{G}_{8}$, which located in the interior of and beyond the triplex-forming region, respectively. These results strongly suggest that the photoinjected hole was mainly trapped at $\mathrm{G}_{18} \mathrm{G}_{19}$ under acidic conditions, where ODN 6 associates with the triplex-forming region of Duplex II into Triplex II and thereby suppress the long-range hole transport over the 
triplex-forming region. The long-range photo-oxidative cleavage experiments are consistent with the results obtained from the separate photocurrent measurements. Thus, a conclusion may be drawn that the duplex-triplex conversion induced by $\mathrm{pH}$ alternation can regulate the hole transport through DNA duplex. ${ }^{18}$

(Fig. 3)

\section{Conclusions}

In summary, we characterized the $\mathrm{pH}$ effect on the hole transport through an AQ-linked DNA duplex possessing a partial triplex-forming region. The photocurrent responses due to the hole transport through DNA duplex immobilized on a gold electrode was clearly decreased under acidic conditions, where formation of a partial triplex structure occurred to effectively suppress the hole transport. Under basic conditions, on the other hand, the triplex dissociated into the corresponding duplex and

a short strand to enhance the hole transport and thereby photocurrent response. Additionally, we confirmed that the photocurrent characteristics can be correlated to the long-range photo-oxidative DNA cleavage results, which showed that the DNA 
cleavages at the hole trapping sites beyond the triplex-forming region was efficiently suppressed by partial triplex formation under acidic conditions. This property of DNA triplexes would provide a useful functionality of on/off regulation of the hole transport upon cyclic alternation of $\mathrm{pH}$ values. Such a regulation method will facilitate a possible application of DNA duplexes to potential nano-scale devices. 


\section{Experimental}

Material. Modified oligodeoxynucleotide (ODN 1, ODN 2 and ODN 5) were synthesized by the previously reported method. ${ }^{6,8,14}$ In the measurement of photocurrent with amperometry, the reagents for DNA synthesis were purchased from Glen Research. ODNs, T4 polynucleotide kinase, and $\gamma-\left[{ }^{32} \mathrm{P}\right]$-ATP $(10 \mathrm{mCi} / \mathrm{ml})$ were used as received from Invitrogen, NIPPON GENE (10 unites/ $\mu \mathrm{L}$ ), and Amersham Bioscience, respectively. All aqueous solutions were prepared using purified water (YAMATO, WR600A).

Instrumentation. UV absortion spectra were recorded on a Jasco V-530. Photoirradiation at $365 \mathrm{~nm}$ for DNA cleavage experiment was carried out using a ULTRA-VIOLET PRODUCTS NTFL-40 transilluminator, and a $100 \mathrm{~W}$ UV lamp (ASAHI SPECTRA, LAX101) with monochromatic excitation light through a $365 \pm 5$ $\mathrm{nm}$ band pass filter (ASAHI SPECTRA, $\phi 25 \mathrm{~mm}$ ) was used for the measurement of photocurrent responses. A GIBCO BRL Model S2 sequencing gel electrophoresis apparatus was used for PAGE. The gels were analyzed by densitometry with an ATTO Lane Analyzer (version 3). The photocurrent was measured in a three-electrode 
arrangement (ALS, model 660B). Mass spectrometry of oligodeoxynucleotides (ODNs) were performed with a MALDI-TOF MS (Perseptive Voager Elite, acceleration voltage $21 \mathrm{kV}$, negative mode) with 2',3',4'-trihydroxyacetophenone as a matrix, using $\mathrm{T}_{8}$ $\left([\mathrm{M}-\mathrm{H}]^{-}\right.$2370.61), $\mathrm{T}_{17}\left([\mathrm{M}-\mathrm{H}]^{-}\right.$5108.37) and $\mathrm{T}_{27}\left([\mathrm{M}-\mathrm{H}]^{-}\right.$8150.33) as the internal standards. Reversed-phase HPLC was performed with Shimadzu 10A or HITACHI D-7000 HPLC system. Sample solutions were injected on a reversed phase column (Inertial ODS-3, GL Science Inc, $\phi 4.6 \mathrm{~mm} \times 150 \mathrm{~mm}$ ).

DNA characterization. Each ODN synthesized in this study was characterized by MALDI-TOF MS: 5'-TACGGAAGGAAGAGGGAGTC- $\left(\mathrm{CH}_{2}\right)_{6}$-S-S- $\left.\left(\mathrm{CH}_{2}\right)_{6}-\mathrm{T}\right)-3^{\prime}, \mathrm{m} / \mathrm{z}$ 6911.92 (calcd for $[\mathrm{M}-\mathrm{H}]^{-}$6911.71); 5'-GACTCCCTCTTCCTTCCG ${ }^{\mathrm{AQ}} \mathrm{UA}-3^{\prime} \mathrm{m} / \mathrm{z}$ 6286.60 (calcd for $[\mathrm{M}-\mathrm{H}]^{-}$6286.16); 5'-AQ'-TTTAGCCACTTCTCTACCTGATAG-3', $\mathrm{m} / \mathrm{z} 7665.51$ (calcd for $[\mathrm{M}-\mathrm{H}]^{-}$7666.05)

$\boldsymbol{T}_{\mathbf{m}}$ Measurement. $2.5 \mu \mathrm{M}$ solutions of the appropriate ODNs in a reaction buffer (10 $\mathrm{mM}$ sodium cacodylate buffer at $\mathrm{pH} 5.5,6.8$ or 7.7 and $2 \mathrm{mM} \mathrm{MgCl} 2$ ) were prepared to determine the melting temperatures $\left(T_{\mathrm{m}}\right)$ of duplex and triplex. Duplex formation was achieved by heating the sample at $90{ }^{\circ} \mathrm{C}$ for $5 \mathrm{~min}$ and slowly cooling to room 
temperature. Furthermore, a partial triplex formation was achieved by cooling at $4{ }^{\circ} \mathrm{C}$ for $12 \mathrm{~h}$ after addition of a third strand to the duplex sample. Melting curves were obtained by monitoring variation of the UV absorbance at $260 \mathrm{~nm}$ with elevating temperatures from $2{ }^{\circ} \mathrm{C}$ to $90{ }^{\circ} \mathrm{C}$ at a rate of $1{ }^{\circ} \mathrm{C} / \mathrm{min}$.

Immobilization of Thiolated ODN 1 on a Gold Electrode. A gold electrode with 2 $\mathrm{mm}^{2}$ in area was used for this study. Prior to ODN immobilization, the electrode was soaked in boiling $2 \mathrm{M}$ potassium hydroxide for 3 hours and washed with deionized water. Following this treatment, the electrode was further soaked in concentrated nitric acid for 1 hour and washed with deionized water. For chemisorption of ODN 1, a $1 \mu \mathrm{L}$ solution of $5 \mu \mathrm{M}$ thiolated ODN 1 was placed on a gold electrode turned upside-down and the opening of the electrode vessel was then stuffed with a rubber stopper to avoid evaporation of the solvent. After leaving the assembly for 2 hours at room temperature, a $1 \mu \mathrm{L}$ solution of $1 \mathrm{mM}$ 6-mercaptohexanol in deionized water was placed on a gold electrode for masking of the gold surface and the opening of electrode vessel was stuffed with a rubber stopper, again. After leaving the assembly for 1 hour at room temperature, the electrode was carefully washed with small amount of deionized water. For the duplex formation with thiolated ODN 1 immobilized on a gold electrode, $1 \mu \mathrm{L}$ 
of $10 \mu \mathrm{M}$ AQ-linked ODN 2 in aqueous solution was placed on a gold electrode turned upside-down and the opening of electrode vessel was then stuffed with a rubber stopper. The assembly (Duplex I) was left for 2 hours at $4{ }^{\circ} \mathrm{C}$ prior to photoelectrochemical measurement. For the triplex formation with the third strand (ODN 3), $1 \mu \mathrm{L}$ of $20 \mu \mathrm{M}$ ODN 3 in $10 \mathrm{mM}$ sodium cacodylate buffer ( $\mathrm{pH} 5.5$ ) containing $2 \mathrm{mM} \mathrm{MgCl}_{2}$ was placed on a duplex-modified gold electrode turned upside-down and the opening of electrode vessel was then stuffed with a rubber stopper. The assembly (Triplex I) was left for 12 hours at $4{ }^{\circ} \mathrm{C}$ prior to photoelectrochemical measurement.

Photoelectrochemical Measurement. Photocurrents were measured for solutions in 10 $\mathrm{mM}$ sodium cacodylate buffer ( $\mathrm{pH}$ 5.5) containing $2 \mathrm{mM} \mathrm{MgCl}_{2}$ in a one-compartment Pyrex cell at an applied potential of $500 \mathrm{mV}$ vs SCE under illumination by a $100 \mathrm{~W} \mathrm{UV}$ lamp with monochromatic excitation light through a $365 \pm 5 \mathrm{~nm}$ band pass filter. The cell for photocurrent measurement consisted of a three-electrode arrangement (ALS, model 660B) of a modified Au working electrode (electrode area, $2 \mathrm{~mm}^{2}$ ), a platinum counter electrode and an SCE reference electrode. The measurements of triplex samples were performed in $10 \mathrm{mM}$ sodium cacodylate buffer containing $2 \mathrm{mM} \mathrm{MgCl}_{2}$ and $2 \mu \mathrm{M}$ ODN 3 at $15{ }^{\circ} \mathrm{C}$. The duplex-triplex conversion was accomplished by cyclic alteration 
of $\mathrm{pH}$ value between 5.5 and 7.7, which was achieved by addition of appropriate amount of $5 \mathrm{M} \mathrm{NaOH}$ or $5 \mathrm{M} \mathrm{HCl}$ to buffer solution. The solution was kept at $15{ }^{\circ} \mathrm{C}$ for 15 min before each photocurrent measurements.

Preparation of 5'-32 P-End-Labeled ODN 4. ODN 4 ( 400 pmol strand concentration) were labeled by phosphorylation with $4 \mu \mathrm{L}$ of $\left[\gamma^{32} \mathrm{P}\right]$ ATP and $4 \mu \mathrm{L}$ of $\mathrm{T}_{4}$ polynucleotide kinase using standard procedures. ${ }^{19}$ The 5 '-end-labeled ODN 4 were recovered by ethanol precipitation, further purified by $15 \%$ nondenaturing gel electrophoresis, and then isolated by the crush and soak method.

General Procedures for Photoinduced Cleavage of ${ }^{32} \mathrm{P}-5$ '-End-Labeled Triplex II. Triplex samples were prepared by hybridizing a mixture of cold and radiolabeled ODN $4(1 \mu \mathrm{M})$ with $1 \mu \mathrm{M}$ of ODN 5 and $1 \mu \mathrm{M}$ of ODN 6 in sodium cacodylate buffer containing $2 \mathrm{mM} \mathrm{MgCl} 2$ at a given $\mathrm{pH}$ value. The ${ }^{32} \mathrm{P}-5$ '-end-labeled Triplex II were irradiated at $365 \mathrm{~nm}$ at $0{ }^{\circ} \mathrm{C}$ under given $\mathrm{pH}$ conditions. After photoirradiation, all reaction mixtures were precipitated with addition of $10 \mu \mathrm{L}$ of herring sperm DNA (1 $\mathrm{mg} / \mathrm{mL}), 10 \mu \mathrm{L}$ of $3 \mathrm{M}$ sodium acetate and $800 \mu \mathrm{L}$ of ethanol. The precipitated DNA 
was washed with $100 \mu \mathrm{L}$ of $80 \%$ cold ethanol and dried in vacuo. The resulting DNA was resolved in $50 \mu \mathrm{L}$ of $10 \%$ piperidine $(\mathrm{v} / \mathrm{v})$, heated at $90{ }^{\circ} \mathrm{C}$ for $20 \mathrm{~min}$ and then concentrated. The radioactivity of the samples was assayed using an Aloka 1000 liquid scintillation counter and the dried DNA pellets were resuspended in $80 \%$ formamide loading buffer (a solution of $80 \%$ formamide (v/v), 1 mM EDTA, $0.1 \%$ xylene cyanol and $0.1 \%$ bromophenol blue). All reactions, along with the Maxam-Gilbert G+A sequencing reactions were heat-denatured at $90{ }^{\circ} \mathrm{C}$ for 3 min and quickly chilled on ice. The samples $\left(1-2 \mu \mathrm{L}, 2-5 \times 10^{3} \mathrm{cpm}\right)$ were loaded onto $15 \%$ of polyacrylamide/7 $\mathrm{M}$ urea sequencing gels, electrophoresed at $1900 \mathrm{~V}$ for $60 \mathrm{~min}$, transferred to a cassette and then stored at $-80{ }^{\circ} \mathrm{C}$ with Fuji X-ray film (RX-U). The gels were analyzed by autoradiography with the ATTO densitograph software library (version 3.0). The intensity of the spots resulting from piperidine treatment was determined by volume integration.

\section{Acknowledgements}

We acknowledge Dr. Akimitsu Okamoto (RIKEN) for providing guidance in the 
experimental techniques of photocurrent measurements.

Electronic supplementary information (ESI) available: UV data for the measurement

of melting temperature and gel picture for the long-range oxidative cleavage of Triplex

II with $\mathrm{pH}$ change. 


\section{References and Notes}

1 (a) M. E. Núñez, J. K. Barton, Curr. Opin. Chem. Biol. 2000, 4, 199-206. (b) G.

B. Schuster, Ed., Long-Range Charge Transfer in DNA I, Springer, Heidelberg,

Germany, 2004. (c) G. B. Schuster, Ed., Long-Range Charge Transfer in DNA II, Springer, Heidelberg, Germany, 2004. (d) R. Tashiro, H. Sugiyama, Angew. Chem. Int. Ed. 2003, 42, 6018-6020.

(a) E. M. Boon, D. M. Ceres, T. G. Drummond, M. G. Hill, J. K. Barton, Nat.

Biotechnol. 2000, 18, 1096-1100. (b) A. K. Boal, E. Yavin, O. A. Lukianova, V.

L. O’Shea, S. S. David, J. K. Barton, Biochemistry 2005, 44, 8397-8407.

(a) H. -W. Fink, C. Schönenberger, Nature 1999, 398, 407-410. (b) D. Porath,

A. Bezryadin, S. de Vries, C. dekker, Nature 2000, 403, 635-638. (c) K.

Tanaka, A. Tengeiji, T. Kato, N. Toyama, M. Shionoya, M. Science 2003, 299, $1212-1213$.

(a) I. Okamoto, M. Nabeta, Y. Hayakawa, N. Morita, T. Takeya, H. Masu, I.

Azumaya, O. Tamura, J. Am. Chem. Soc., 2007, 129, 1892-1893. (b) K. M.

Sun, C. K. McLaughlin, D. R. Lantero, R. A. Manderville, J. Am. Chem. Soc, 2007, 129, 1894-1895. (c) Y. Lee, S. Fukushima, Y. Bae, S. Hiki, T. Ishii, K. Kataoka, J. Am. Chem. Soc. 2007, 129, 5362-5363. 
J. L. Asensio, A. N. Lane, J. Dhesi, S. Bergqvist, T. Brown, J. Mol. Biol. 1998, $275,811-822$.

K. Tanabe, H. Iida, K. Haruna, T. Kamei, A. Okamoto, S. Nishimoto, J. Am.

Chem. Soc. 2006, 128, 692-693.

(a) Y. Kan, G. B. Schuster, J. Am. Chem. Soc. 1999, 121, 11607-11614. (b) M.

E. Núñez, K. T. Noyes, D. A. Gianolio, L. W. McLaughln, J. K. Barton, Biochemistry 2000, 39, 6190-6199. (c) A. Okamoto, K. Tanabe, C. Dohno, I. Saito, Bioorg. Med. Chem. 2002, 10, 713-718.

(a) H. Yamada, K. Tanabe, S. Nishimoto, Org. Biomol. Chem. 2008, 6, 272-277. (b) A. Okamoto, T. Kamei, K. Tanaka, I. Saito, J. Am. Chem. Soc. 2006, 128, 658-662.

Excess amount of a blocking agent $\mathrm{MCH}$ could form effectively the $\mathrm{MCH}$ monolayer on the electrode to replace unfavorable thiol-modified ODNs with non-specific and weak interactions between their nucleotide bases and the surface of gold electrode. The MCH monolayer would also minimize a direct contact of AQ photosensitizer at the 3'-end of ODN with the gold electrode. See: Herne, T. M.; Tarlov, M. J. J. Am. Chem. Soc. 1997, 119, 8916, ref. 6 and ref. 8 . 
A. B. Steel, T. M. Herne, M. J. Tarlov, Anal. Chem. 1998, 70, 4670-4677.

11 We confirmed that the $T_{\mathrm{m}}$ values of duplex and triplex after cyclic $\mathrm{pH}$ change were similar to those before $\mathrm{pH}$ alteration.

12 The degradation of ODNs immobilized on a gold electrode possibly occurring upon $\mathrm{pH}$ alternation may be partly responsible for the slight decrease in photocurrent density.

13 R. N. Barnet, C. L. Cleveland, A. Joy, U. Landman, G. B. Schuster, Science 2001, 294, 567-571.

14 R. P. Fahlman, D. Sen, J. Am. Chem. Soc. 2002, 124, 4610-4616.

15 Consecutive purine bases such as guanine doublets (GG) are known to be an efficient hole trapping site. See, I. Saito, T. Nakamura, K. Nakatani, Y. Yoshioka, K. Yamaguchi, H. Sugiyama, H. J. Am. Chem. Soc. 1998, 120, $12686-12687$.

16 The photosensitized cleavage intensity was normalized using the following equation

$I_{\mathrm{tot}}=\Sigma I_{\mathrm{N}}$

where $I_{\mathrm{N}}$ denotes the intensity of DNA strand cleavage at a given sequence "N" such as $\mathrm{G}_{18} \mathrm{G}_{19}, \mathrm{G}_{7} \mathrm{G}_{8}$ or $\mathrm{G}_{11} \mathrm{AG}_{13}$ site at the respective $\mathrm{pH}$ values, and $I_{\text {tot }}$ 
is the sum of $I_{\mathrm{N}}$ values over the same lane in a gel picture. Thus, the ratio of $I_{\mathrm{N}}$ to $I_{\text {tot }}$ determines the normalized relative amount of DNA cleavage in the relevant sequence that gives the distribution of photoinjected hole.

17 The spontaneous dissociation of Triplex II into the corresponding Duplex II at $\mathrm{pH} 6.8$ was confirmed by the measurements of thermal denaturation profiles (Figure S1). The melting curve of Triplex II at pH 6.8 showed only single transition, which is assigned to dissociation of duplex (i.e. Duplex II) into single strands, while two transitions as in the typical behavior of triplex were observed at $\mathrm{pH} 5.5$.

18 We also confirmed the recovery of hole transport efficiency in DNA by increasing $\mathrm{pH}$ value in the long-range photo-oxidative DNA cleavage experiments. Thus, the cleavage at $\mathrm{G}_{7} \mathrm{G}_{8}$ in Triplex II was enhanced by increasing $\mathrm{pH}$ value from 5.5 to 6.8. (See, Figure S2).

19 (a) A. M. Maxam, W. Gilbert, Proc. Natl. Acad. Sci. U. S. A. 1977, 74, 560-564. (b) T. Maniatis, E. F. Fritsch, J. Sambrook, Molecular Cloning, Cold Spring Harbor Laboratory Press, Plainview, New York, 1982. (c) J. Sambrook, E. F. Fritsch, T. Maniatis, Molecular Cloning: A Laboratory Manual, 2nd Ed., Cold Spring Harbor Laboratory Press, New York, 1989. 
ODN 1: 5'-TAC GGA AGG AAG AGG GAG TC- $\left(\mathrm{CH}_{2}\right)_{6}-\mathrm{SAu}-3$ '

ODN 2: 3'-AQUG CCT TCC TTC TCC CTC AG-5'

ODN 3:

$5^{\prime}-$ CCT TCC TTC-3'

Duplex I: ODN 1/ ODN 2

Triplex I: ODN 1/ ODN 2/ODN 3

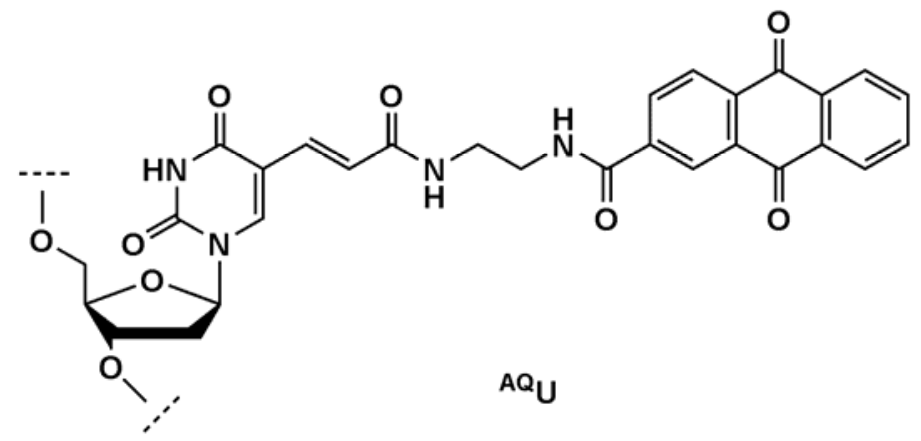

ODN 4: 5'-CTA TCA G $\mathrm{G}_{7} \mathrm{G}$ T AGA GAA GTG $_{18} \mathrm{G}_{19}$ CT AAA-3' ODN 5: 3'-GAT AGT CCA TCT CTT CAC CGA TTT-AQ'-5' ODN 6: 5'-TCT CTT C-3'

Triplex II: ODN 4/ ODN 5/ODN 6<smiles>NC(=O)C(=O)OP(=O)([O-])O[Mg]C(=O)NC(=O)c1ccc2c(c1)C(=O)c1ccccc1C2=O</smiles>

Fig. 1. Sequences and structures of oligodeoxynucleotides (ODNs) used in this study. The bases arranged in the triplex region are shown in italics. 
(a)

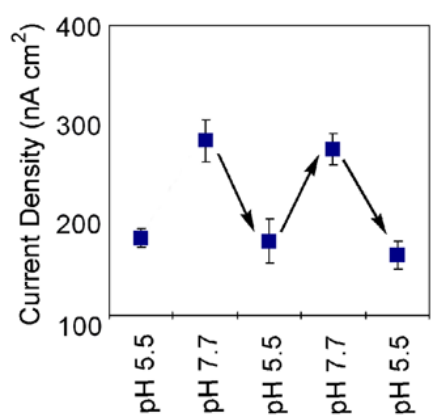

(b)

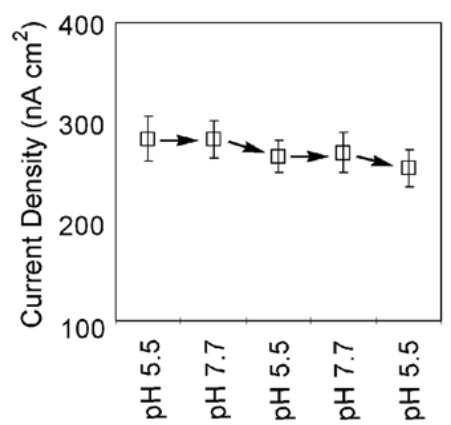

(c)

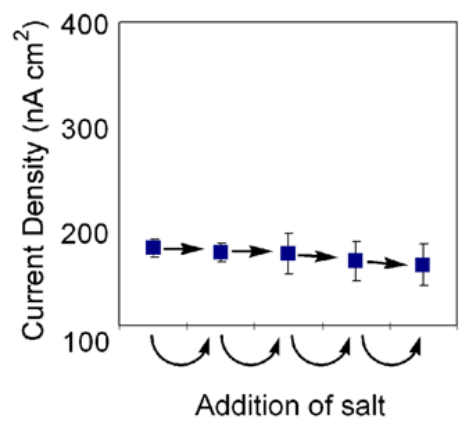

Fig. 2. (a, b) Reversible regulation of the photocurrent response by alternating duplex-triplex conversion at a $\mathrm{pH}$ cycle, as evaluated at an applied potential of $500 \mathrm{mV}$ vs. SCE. The Duplex I (ODN 1/ODN 2) immobilized on the gold electrode were photoirradiated $\left(365 \pm 5 \mathrm{~nm}\right.$ light at $\left.13.0 \pm 0.3 \mathrm{~mW} \mathrm{~cm}^{-2}\right)$ at $15{ }^{\circ} \mathrm{C}$ in $10 \mathrm{mM}$ sodium cacodylate buffer containing $2 \mathrm{mM} \mathrm{MgCl}_{2}$ upon cyclic alternation of $\mathrm{pH}$ condition between 5.5 and 7.7 in the presence (a) and absence (b) of the third strand (ODN 3), respectively. The $\mathrm{pH}$ change was achieved by addition of appropriate amount of $5 \mathrm{M}$ $\mathrm{NaOH}$ or $5 \mathrm{M} \mathrm{HCl}$ aqueous solutions. (c) Effect of ion strength on the photocurrent density of Triplex I immobilized on a gold electrode. To the sodium cacodylate buffer solution ( $\mathrm{pH}$ 5.5), $5 \mathrm{M} \mathrm{NaCl}$ aqueous solution was added each time instead of the addition of $5 \mathrm{M} \mathrm{NaOH}$ or $\mathrm{HCl}$ solutions. The photocurrent responses of Triplex I were measured in a similar manner. Each error bar represents SE calculated from five experimental results that were collected using freshly prepared different gold electrodes. 
(a)

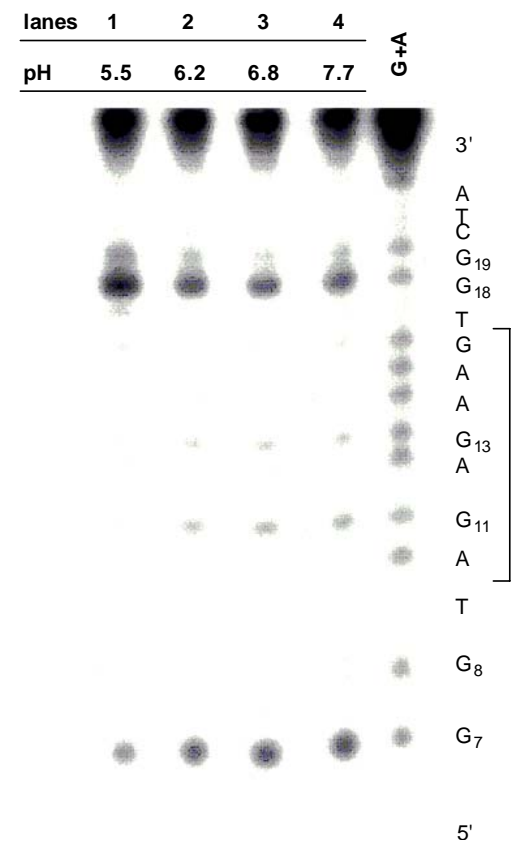

(b)

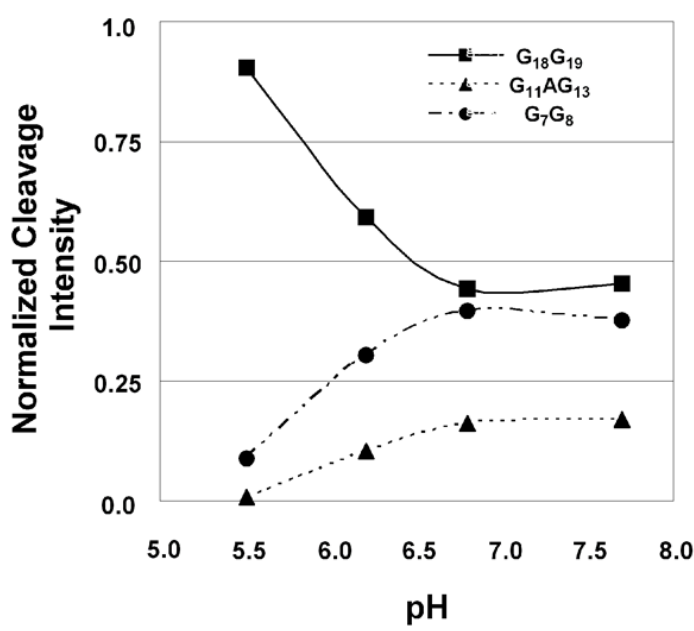

Fig. 3. (a) Autoradiogram of a denaturing gel electrophoresis for ${ }^{32} \mathrm{P}-5$ '-end labeled ODN 4 after photooxidation of Triplex II (ODN 4/ODN 5/ODN 6). Each sample in 10 $\mathrm{mM}$ sodium cacodylate containing $2 \mathrm{mM} \mathrm{MgCl}_{2}$ was photoirradiated $\left(\lambda_{\text {ex }}=365 \mathrm{~nm}\right)$ at $0{ }^{\circ} \mathrm{C}$, followed by hot piperidine treatment. Lanes 1-4, photoirradiation of Triplex II for 30 min at $\mathrm{pH}$ 5.5, 6.2, 6.8 and 7.7, respectively. The lane labeled $\mathrm{G}+\mathrm{A}$ is Maxam-Gilbert sequencing lane. The designed triplex-forming site is indicated by a bracket. (b) The normalized intensity of photooxidative cleavage in Figure $3 \mathrm{a}$ as a function of $\mathrm{pH}$ value: (匹) $\mathrm{G}_{18} \mathrm{G}_{19},(\boldsymbol{\Delta}) \mathrm{G}_{11} \mathrm{AG}_{13}$ and $(\bullet) \mathrm{G}_{7} \mathrm{G}_{8}$ in ODN 4 . 